\title{
Involvement of $N$-acylethanolamine-hydrolyzing acid amidase in the degradation of anandamide and other $N$-acylethanolamines in macrophages
}

\author{
Yong-Xin Sun ${ }^{\text {a }}$, Kazuhito Tsuboi ${ }^{\text {a }}$, Li-Ying Zhao ${ }^{\text {a,b }}$, Yasuo Okamoto ${ }^{\text {a }}$, \\ Didier M. Lambert ${ }^{\mathrm{c}}$, Natsuo Ueda ${ }^{\mathrm{a}, *}$ \\ a Department of Biochemistry, Kagawa University School of Medicine, 1750-1 Ikenobe, Miki, Kagawa 761-0793, Japan \\ ${ }^{\mathrm{b}}$ Department of Oral and Maxillofacial Surgery, Kagawa University School of Medicine, 1750-1 Ikenobe, Miki, Kagawa 761-0793, Japan \\ ${ }^{\mathrm{c}}$ Unité de Chimie pharmaceutique et de Radiopharmacie, Université catholique de Louvain, Avenue Mounier, 73, UCL-CMFA 73.40, B-1200 Brussels, Belgium
}

Received 22 April 2005; received in revised form 5 August 2005; accepted 17 August 2005

Available online 29 August 2005

\begin{abstract}
Bioactive $N$-acylethanolamines including the endocannabinoid anandamide are known to be hydrolyzed to fatty acids and ethanolamine by fatty acid amide hydrolase (FAAH). In addition, we recently cloned an isozyme termed " $N$-acylethanolamine-hydrolyzing acid amidase (NAAA)", which is active only at acidic pH [Tsuboi, Sun, Okamoto, Araki, Tonai, Ueda, J. Biol. Chem. 285 (2005) 11082-11092]. However, physiological roles of NAAA remained unclear. Here, we examined a possible contribution of NAAA to the degradation of various $N$ acylethanolamines in macrophage cells. NAAA mRNA as well as FAAH mRNA was detected in several macrophage-like cells, including RAW264.7, and mouse peritoneal macrophages. The homogenates of RAW264.7 cells showed both the NAAA and FAAH activities which were confirmed with the aid of their respective specific inhibitors, $N$-cyclohexanecarbonylpentadecylamine (CCP) and URB597. As analyzed with intact cells, RAW264.7 cells and peritoneal macrophages degraded anandamide, $N$-palmitoylethanolamine, $N$-oleoylethanolamine, and $N$ stearoylethanolamine. Pretreatment of the cells with CCP or URB597 partially inhibited the degradation, and a combination of the two compounds caused more profound inhibition. In contrast, the anandamide hydrolysis in mouse brain appeared to be principally attributable to FAAH despite the expression of NAAA in the brain. These results suggested that NAAA and FAAH cooperatively degraded various $N$-acylethanolamines in macrophages.
\end{abstract}

(C) 2005 Elsevier B.V. All rights reserved.

Keywords: $N$-Acylethanolamine; $N$-Acylethanolamine-hydrolyzing acid amidase; Anandamide; Endocannabinoid; Macrophage; Fatty acid amide hydrolase

\section{Introduction}

$N$-Acylethanolamines are ethanolamides of long-chain fatty acids that exist ubiquitously in animal tissues [1-4]. This class of lipids has been noted because of their biological activities. In particular, anandamide ( $N$-arachidonoylethanolamine) was identified as an endogenous ligand of cannabinoid receptor CB1 [5], which actually shows a series of cannabimimetic activities [6]. Anandamide was also reported to be an agonist of the transient receptor potential vanilloid type 1 [7]. NPalmitoylethanolamine is inactive with cannabinoid receptors, but is known as an anti-inflammatory and analgesic substance

\footnotetext{
* Corresponding author. Tel.: +81 87891 2102; fax: +81 878912105 .

E-mail address: nueda@med.kagawa-u.ac.jp (N. Ueda).
}

[8-10]. Recently, it was shown that the anti-inflammatory action of this compound could be mediated by the activation of peroxisome proliferator-activated receptor- $\alpha$ (PPAR- $\alpha)$ [11]. Furthermore, $N$-oleoylethanolamine has an anorexic effect via PPAR- $\alpha[12,13]$, and $N$-stearoylethanolamine is pro-apoptotic [14] and anorexic [15]. It has also been noted that these $\mathrm{N}$ acylethanolamines increase markedly in degenerating tissues and cells [16-19]. $N$-Acylethanolamines are formed from their corresponding $N$-acyl-phosphatidylethanolamines by a phospholipase D-type enzyme. Our recent cDNA cloning demonstrated that this enzyme is a novel phospholipase D specific for $N$-acyl-phosphatidylethanolamines, strongly suggesting the physiological significance of $N$-acylethanolamines [20].

$\mathrm{N}$-Acylethanolamines including anandamide are inactivated principally by enzymatic hydrolysis to free fatty acids and ethanolamine [21-25]. Fatty acid amide hydrolase (FAAH) 
was discovered as the first enzyme responsible for this reaction in animal tissues [21-25]. FAAH is a membrane-bound serine hydrolase, and is characterized by the optimal $\mathrm{pH}$ value at $8.5-$ 10. The enzyme has been suggested to play the central role in the $N$-acylethanolamine degradation because of its high activity and wide distribution in animal tissues [21-23]. Recent studies with FAAH-deficient mice revealed that their brain levels of anandamide, $N$-palmitoylethanolamine, and $N$-oleoylethanolamine were much higher than those in wild-type mice, supporting the physiological importance of FAAH [26,27].

In addition to FAAH, we found a second $N$-acylethanolamine hydrolase, first in human megakaryoblastic cells [28] and later in various rat tissues including lung, spleen, and macrophages [29]. This enzyme, termed as " $N$-acylethanolamine-hydrolyzing acid amidase (NAAA)", was active only at acidic $\mathrm{pH}$ and was catalytically distinct from FAAH [30]. Very recently, we cloned cDNA for NAAA from human, mouse, and rat and expressed a functionally active recombinant NAAA in mammalian cells [31]. As compared at amino acid levels, NAAA showed no sequence homology with FAAH, but a 33$34 \%$ homology with acid ceramidase. The recombinant enzyme hydrolyzed various $N$-acylethanolamines with the highest reactivity with $\mathrm{N}$-palmitoylethanolamine as reported with rat lung NAAA [31].

Anandamide and other $N$-acylethanolamines have been isolated from macrophages [32-38]. Macrophage-derived anandamide was suggested to be implicated in endotoxininduced hypotension [36], and $\mathrm{N}$-palmitoylethanolamine was shown to inhibit the generation of nitric oxide in macrophages [39]. Although the expression of FAAH in macrophages was previously reported $[38,40,41]$, the endogenous anandamide level in the peritoneal macrophages of FAAH-deficient mice was only 2- to 2.5 -fold higher than that of wild-type mice [38]. On the other hand, we found a high NAAA activity in rat peritoneal and alveolar macrophages with $N$-palmitoylethanolamine as a substrate $[29,42]$. Therefore, it was of interest to examine how NAAA and FAAH share in the degradation of $N$ acylethanolamines in macrophages. In the present study, we investigated expression levels of NAAA as well as FAAH in various types of macrophage-like cells by RT-PCR, and then the capability of FAAH and NAAA to degrade exogenously added $N$-acylethanolamines in macrophages. To distinguish the NAAA activity from the FAAH activity, we successfully used URB597 [43,44] and cyclohexanecarbonylpentadecylamine (CCP) [42] as selective inhibitors of FAAH and NAAA, respectively. Our results suggest significant contribution of NAAA to the degradation of various $N$-acylethanolamines in macrophages.

\section{Materials and methods}

\subsection{Materials}

$\left[1-{ }^{14} \mathrm{C}\right]$ Palmitic acid was purchased from PerkinElmer Life Science (Boston, MA); $\left[1-{ }^{14} \mathrm{C}\right]$ arachidonic, $\left[1-{ }^{14} \mathrm{C}\right]$ oleic, and $\left[1-{ }^{14} \mathrm{C}\right]$ stearic acids from Amersham Biosciences (Piscataway, NJ); arachidonic acid from $\mathrm{Nu}-$ Chek-Prep (Elysian, MN); palmitic, oleic, and stearic acids, nordihydroguaiaretic acid (NDGA), and lipopolysaccharide (Escherichia coli O127:B8) from Sigma (St. Louis, MO); $N$-palmitoylethanolamine, $N$-heptadecanoylethanolamine, anandamide, and URB597 from Cayman Chemical (Ann Arbor, MI); dithiothreitol (DTT) from Wako Pure Chemical (Osaka, Japan); Triton X-100 and RPMI medium 1640 from Nacalai Tesque (Kyoto, Japan); protein assay dye reagent concentrate from Bio-Rad (Hercules, CA); precoated silica gel $60 \mathrm{~F}_{254}$ aluminum sheets for thin-layer chromatography (TLC) $(20 \times 20 \mathrm{~cm}, 0.2 \mathrm{~mm}$ thickness) from Merck (Darmstadt, Germany); Trizol, Moloney murine leukemia virus-reverse transcriptase, and Ham's F-12 medium from Invitrogen (Carlsbad, CA); fetal calf serum from PAA Laboratories (Linz, Austria); RAW264.7 cells from American Type Culture Collection (Rockville, MD); P388-D1, J774.1, and THP-1 cells from Health Science Research Resources Bank (Osaka, Japan). U937 cells were kindly provided by Dr. Hitoshi Arita of Shionogi Research Laboratories (Osaka, Japan). $N-\left[{ }^{14} \mathrm{C}\right]$ Acylethanolamines were synthesized from $1-{ }^{14} \mathrm{C}$-labeled fatty acids and ethanolamine as described previously [45]. CCP was synthesized as described previously [42].

\subsection{Cell culture}

RAW264.7, P388-D1, U937, and THP-1 cells were cultured in RPMI medium 1640 supplemented with $10 \%$ heat-inactivated fetal calf serum, penicillin $(100$ units $/ \mathrm{ml})$, and streptomycin $(100 \mu \mathrm{g} / \mathrm{ml})$ in an incubator controlled at $37{ }^{\circ} \mathrm{C}$ and $5 \% \mathrm{CO}_{2}$. J774.1 cells were cultured in Ham's F-12 medium with $10 \%$ heat-inactivated fetal calf serum, penicillin (100 units $/ \mathrm{ml})$, and streptomycin $(100 \mu \mathrm{g} / \mathrm{ml})$.

\subsection{RT-PCR}

Total RNA was isolated with Trizol reagent from various macrophage cells of mouse and human and organs of mouse (C57BL/6, Japan SLC, Hamamatsu, Japan). cDNAs were then synthesized by the use of Moloney murine leukemia virus-reverse transcriptase and random hexamer, and were subjected to PCR amplification. Primers used were as follows: for mouse NAAA, 5'-ATTCTGCACCAGTATTGTGGCCCAAGACTC-3' (sense) and 5'TCCATTCAGAGGGTCAAGAGGCCAAATGTC- $3^{\prime}$ (antisense); for human NAAA, 5'-AAGACTCCAGAGGCCACATTTACCATGGTC-3' (sense) and 5'-CATCAGCAATAAGGGGAGTCTTGGCCAACT-3' (antisense); for mouse and human FAAH, 5'-GCCTGGGAAGTGAACAAAGGGACC-3' (sense) and 5'-CTTCAGGCCACTCTTGCTGAGGCG-3' (antisense); for mouse glyceraldehyde-3-phosphate dehydrogenase (GAPDH), 5'-TGAAGGTCGGTGTGAACGGATTTGGC-3' (sense) and 5'-CATGTAGGCCATGAGGTCCACCAC-3' (antisense); for human GAPDH, 5'-AAGGTCGGAGTCAACGGATTTGG-3' (sense) and 5'-ACGAACATGGGGGCATCAGC-3' (antisense). PCR conditions used were as follows: for NAAA, denaturation at $94{ }^{\circ} \mathrm{C}$ for $30 \mathrm{~s}$, annealing at $64{ }^{\circ} \mathrm{C}$ for $30 \mathrm{~s}$, and extension at $72{ }^{\circ} \mathrm{C}$ for $48 \mathrm{~s}$ (26 cycles); for FAAH, denaturation at $94{ }^{\circ} \mathrm{C}$ for $48 \mathrm{~s}$, annealing at $62{ }^{\circ} \mathrm{C}$ for $48 \mathrm{~s}$, and extension at $72{ }^{\circ} \mathrm{C}$ for $48 \mathrm{~s}$ (30 cycles); for GAPDH, denaturation at $95{ }^{\circ} \mathrm{C}$ for $30 \mathrm{~s}$, annealing at $58^{\circ} \mathrm{C}$ for $15 \mathrm{~s}$, and extension at $72{ }^{\circ} \mathrm{C}$ for $30 \mathrm{~s}$ (27 cycles). PCR products, which were confirmed to be in the logarithmic phases, were electrophoresed on $1.2-1.8 \%$ agarose gels and stained with ethidium bromide.

\subsection{Preparation of enzymes}

Male Wistar rats (250-500 g weight, Charles River Japan) and male C57BL/6 mice (22-27 g weight, Japan SLC) were deeply anesthetized by diethyl ether and sacrificed by cervical dislocation or decapitation. The lung and liver of rats were removed and homogenized in 9 times the volume $(\mathrm{v} / \mathrm{w})$ of ice-cold $20 \mathrm{mM}$ Tris- $\mathrm{HCl}(\mathrm{pH}$ 7.4) containing $0.32 \mathrm{M}$ sucrose with a Polytron homogenizer. The homogenates were centrifuged at $800 \times g$ for $15 \mathrm{~min}$. In the case of the lung homogenate, the supernatant was then centrifuged at $12,000 \times \mathrm{g}$ for $30 \mathrm{~min}$. The $12,000 \times \mathrm{g}$ pellet was suspended in phosphate-buffered saline (PBS) (pH 7.4) and subjected to two cycles of freezing and thawing. The sample was then centrifuged at $105,000 \times g$ for $50 \mathrm{~min}$, and the resultant supernatant was used for the NAAA assay. As for the liver homogenates, the $800 \times g$ supernatant was centrifuged at $105,000 \times g$ for $55 \mathrm{~min}$, and the pellet was suspended in $50 \mathrm{mM}$ Tris- $\mathrm{HCl}(\mathrm{pH} 7.4)$ containing $1 \%(\mathrm{w} / \mathrm{v})$ Triton X100. The supernatant obtained by further centrifugation at $105,000 \times g$ for 50 
min was used for FAAH assay. Protein concentration was determined by the method of Bradford [46] with bovine serum albumin as standard.

\subsection{Enzyme assay}

The samples were allowed to react at $37{ }^{\circ} \mathrm{C}$ for 30 min with $100 \mu \mathrm{M} \mathrm{N}$ $\left[{ }^{14} \mathrm{C}\right]$ acylethanolamine $(10,000 \mathrm{cpm}$, dissolved in $5 \mu \mathrm{l}$ of dimethyl sulfoxide (DMSO)) in $100 \mu \mathrm{l}$ of $50 \mathrm{mM}$ citrate-sodium phosphate $(\mathrm{pH} 5.0)$ containing $0.1 \%$ Triton X-100 and $3 \mathrm{mM}$ DTT (for NAAA assay) or in $100 \mu \mathrm{l}$ of $50 \mathrm{mM}$ Tris $-\mathrm{HCl}$ ( $\mathrm{pH}$ 9.0) (for FAAH assay). CCP or URB597 dissolved in $5 \mu 1$ of DMSO/ethanol (9:1) was also included when indicated. The reaction was terminated by addition of $0.35 \mathrm{ml}$ of a mixture of diethyl ether/methanol/1 M citric acid (30:4:1, v/v) containing $5 \mathrm{mM} 3(2)$-t-butyl-4-hydroxyanisole (BHA). The ether extract $(100 \mu l)$ was then spotted on a silica gel thin-layer plate $(10$ $\mathrm{cm}$ height) and subjected to TLC with a mixture of chloroform $/$ methanol $/ 28 \%$ ammonium hydroxide $(80: 20: 2, \mathrm{v} / \mathrm{v})$ for $25 \mathrm{~min}$ at $4{ }^{\circ} \mathrm{C}$. Radioactivity on the plate was scanned with a BAS1500 bioimaging analyzer (Fujix, Tokyo, Japan). Assays were performed in triplicate.

As for the assays with intact cells, the cells $\left(5 \times 10^{6}\right)$ were suspended in $0.2 \mathrm{ml}$ of RPMI medium 1640 (Fig. 4) or PBS (Fig. 5), and preincubated at $37{ }^{\circ} \mathrm{C}$ for $30 \mathrm{~min}$ in the presence of $1 \mu \mathrm{M}$ URB597, $100 \mu \mathrm{M}$ CCP, or both (dissolved in $5 \mu \mathrm{l}$ of DMSO) or in their absence. The cells were then allowed to react with $25 \mu \mathrm{M}$ of $N-\left[{ }^{14} \mathrm{C}\right]$ acylethanolamine $(5000 \mathrm{cpm})$ at $37{ }^{\circ} \mathrm{C}$ for 30 min. The reaction was terminated by addition of $0.6 \mathrm{ml}$ of a mixture of chloroform/methanol/1 M citric acid (8:4:1, v/v) containing $5 \mathrm{mM}$ BHA. The chloroform extract $(100 \mu \mathrm{l})$ was then spotted on a silica gel thin-layer plate (10 cm height) and subjected to TLC with the organic phase of a mixture of isooctane/ethyl acetate/water/acetic acid $(5: 11: 10: 2, \mathrm{v} / \mathrm{v})$ for $30 \mathrm{~min}$ at room temperature.

\subsection{Measurement of endogenous $\mathrm{N}$-palmitoylethanolamine}

RAW264.7 cells $\left(5 \times 10^{7}\right)$ were cultured in the presence of $100 \mu \mathrm{M} \mathrm{CCP}, 1$ $\mu \mathrm{M}$ URB597, or vehicle alone for $2 \mathrm{~h}$. At $30 \mathrm{~min}$, lipopolysaccharide (10 ng/ $\mathrm{ml})$ was also added. The cells were then collected, and total lipids were extracted from the cell pellet with chloroform/methanol $(2: 1, \mathrm{v} / \mathrm{v})$ twice. $\mathrm{N}$ Heptadecanoylethanolamine (25 pmol) was added as an internal standard. Purification by TLC, derivatization with 1-anthroyl cyanide, and HPLC analysis of $\mathrm{N}$-palmitoylethanolamine were performed according to the method of Sugiura and others [47]. Reverse-phase HPLC was performed by the use of a TSK gel column (type ODS-120T, $5 \mu \mathrm{m}, 4.6 \times 250 \mathrm{~mm}$, Tosoh, Tokyo, Japan) equipped with a Waters 600E System Controller and a Tosoh FS-8000 fluorescence detector (excitation at $370 \mathrm{~nm}$; emission at $470 \mathrm{~nm}$ ).

\section{Results}

We first examined the expression levels of mRNAs for FAAH and NAAA in various macrophage-like cells of mouse (RAW264.7, J774.1, and P388-D1) and human (U937 and THP-1). As analyzed by RT-PCR (Fig. 1), these cell lines except J774.1 were found to express NAAA mRNA as well as FAAH mRNA. In J774.1 cells FAAH mRNA was hardly detectable, and NAAA level was lower than those in other cells. Resident macrophages from the peritoneal cavity of mice also revealed mRNAs for both the enzymes.

We were next interested in finding how NAAA and FAAH shared the $N$-acylethanolamine-hydrolyzing activity in these cells. In order to distinguish the NAAA activity from the FAAH activity, specific inhibitors of each enzyme should be useful tools. We recently reported that CCP was an inhibitor of NAAA with an $\mathrm{IC}_{50}$ of $4.5 \mu \mathrm{M}$ but did not inhibit FAAH at concentrations up to $100 \mu \mathrm{M}$ [42]. In contrast, URB597, which was reported to be a potent inhibitor of FAAH [43], did not

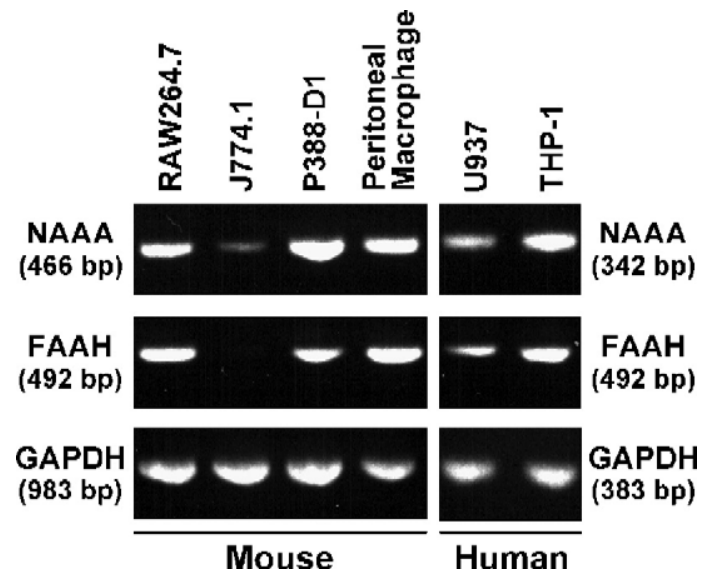

Fig. 1. NAAA and FAAH mRNAs expressed in various macrophage-like cells. Total RNAs were isolated from the indicated macrophage-like cells and peritoneal macrophages, and were analyzed by RT-PCR using primers specific for NAAA, FAAH, and GAPDH. The size of each band is indicated in the parentheses. A representative result of three independent experiments is shown.

inhibit NAAA at concentrations at least up to $10 \mu \mathrm{M}$ (Fig. 2). Under our assay conditions, URB597 dose-dependently inhibited FAAH with an $\mathrm{IC}_{50}$ of $0.07 \mu \mathrm{M}$ and almost completely inhibited the activity at $1 \mu \mathrm{M}$. Therefore, we used CCP and URB597 as a specific NAAA inhibitor and a specific FAAH inhibitor, respectively, in the following enzyme assays.

The anandamide-hydrolyzing activity was first examined in a cell-free system with the homogenates of RAW264.7 cells as a representative macrophage-like cell line. We earlier found that NAAA can be solubilized from the particulate fraction by freezing and thawing while FAAH is not solubilized by the same procedure [28]. Therefore, the homogenates of RAW264.7 cells were subjected to freezing and thawing, and soluble proteins in the homogenates were separated from membrane-bound proteins by centrifugation at $105,000 \times g$. As shown in Fig. 3, when both the soluble proteins and the membrane-bound proteins were allowed to react with anandamide at $\mathrm{pH} 5$ (the optimal $\mathrm{pH}$ of NAAA) or $\mathrm{pH} 9$ (the optimal $\mathrm{pH}$ of FAAH), the highest anandamide-hydrolyzing activity was observed with the soluble proteins at $\mathrm{pH} 5$ (specific enzyme activity, $0.20 \mathrm{nmol} / \mathrm{min}$ per $\mathrm{mg}$ of protein). CCP, but not URB597, inhibited most of this enzyme activity. In addition, a lower activity of the anandamide hydrolysis was detected with the membrane-bound proteins at $\mathrm{pH}$ 9, which was inhibited by URB597, but not by CCP. These results suggested that both NAAA and FAAH of RAW264.7 cells actually functioned as anandamide hydrolases in this cell-free system. Other long-chain $N$-acylethanolamines were also hydrolyzed by the soluble proteins at $\mathrm{pH} 5$ and by the membrane-bound proteins at $\mathrm{pH}$ 9. The relative activity with anandamide, $N$-palmitoylethanolamine, $N$-oleoylethanolamine, and $N$-stearoylethanolamine at $100 \mu \mathrm{M}$ were $100 \%, 107 \%$, $88 \%$, and $21 \%$, respectively, at $\mathrm{pH} 5$; and $100 \%, 117 \%, 54 \%$, and $7 \%$, respectively, at $\mathrm{pH} 9$.

We then examined respective contribution of NAAA and FAAH to the degradation of exogenous $N$-acylethanolamines in the intact RAW264.7 cells. When the cells were incubated 


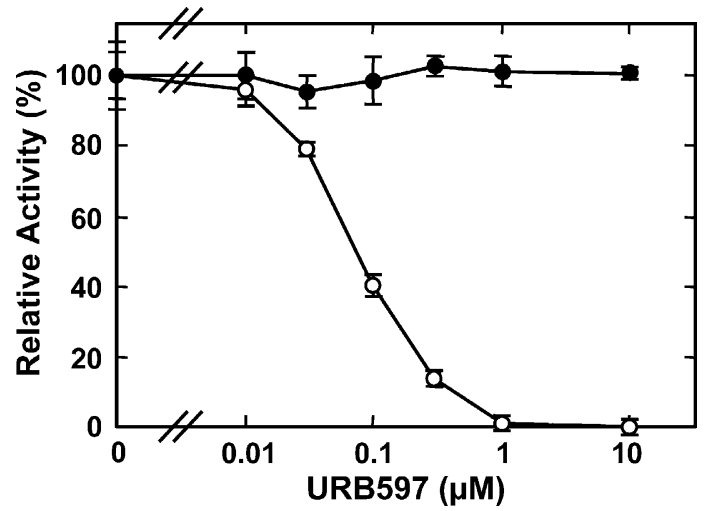

Fig. 2. Inhibitory effect of URB597 on NAAA and FAAH. NAAA from rat lung (closed circles, $8.9 \mu \mathrm{g}$ of protein) and FAAH from rat liver (open circles, $13.7 \mu \mathrm{g}$ of protein) prepared as described under Materials and methods were allowed to react with $100 \mu \mathrm{M} \mathrm{N}-\left[{ }^{14} \mathrm{C}\right]$ palmitoylethanolamine or $100 \mu \mathrm{M}$ $\left[{ }^{14} \mathrm{C}\right]$ anandamide, respectively, in the presence of increasing concentrations of URB597. The activities in the absence of URB597 $(7.5 \mathrm{nmol} / \mathrm{min}$ per $\mathrm{mg}$ of protein for NAAA and $5.9 \mathrm{nmol} / \mathrm{min}$ per $\mathrm{mg}$ of protein for FAAH) were normalized to $100 \%$, and relative activities were shown. Means \pm S.D. are shown $(n=3)$.

with $\left[{ }^{14} \mathrm{C}\right]$ anandamide, the production of ${ }^{14} \mathrm{C}$-labelled polar lipids and non-polar lipids was observed on a thin-layer chromatogram (Fig. 4A). These radioactive bands were decreased by $82 \%$ when the cells were preincubated with CCP (Fig. 4B). URB597 inhibited the reaction weakly (by $19 \%$ ), and a combination of both the inhibitors caused $88 \%$ inhibition. These results suggested that anandamide was hydrolyzed by NAAA and, to a lesser extent, by FAAH in intact RAW264.7 cells, and the produced arachidonic acid appeared to be incorporated to polar lipids and non-polar lipids. Similar assays were also performed with $N$-palmitoyl- ethanolamine (Fig. 4C), $N$-oleoylethanolamine (Fig. 4D), and $N$-stearoylethanolamine (Fig. 4E). CCP and URB597 partially inhibited these reactions, and a combination of both the inhibitors caused more potent inhibition, suggesting the involvement of the two enzymes in the degradation of various $N$-acylethanolamines. Likewise, the degradation of anandamide in intact cells of U937 and THP-1 was partially inhibited by CCP and URB597, respectively (data not shown).

Furthermore, intact cells of mouse peritoneal macrophages also degraded anandamide, $N$-palmitoylethanolamine, $N$ oleoylethanolamine, and $N$-stearoylethanolamine, and the partial inhibition by CCP and URB597 suggested the involvement of both the enzymes in the degradation of these $\mathrm{N}$ acylethanolamines (Fig. 5). When anandamide, but not other $\mathrm{N}$-acylethanolamines, was used as a substrate, several radioactive polar products were observed (data not shown). These compounds were presumed to be formed from anandamide by lipoxygenase since we observed inhibition of the formation of the products by NDGA, a lipoxygenase inhibitor. In accordance with this finding, mouse macrophages were reported to express 12-lipoxygenase [48]. Therefore, the assay with anandamide was performed in the presence of NDGA (Fig. 5A).

The endogenous level of anandamide in RAW264.7 cells was reported to be enhanced by lipopolysaccharide [38]. With this experimental model, we examined the effects of the inhibitors on endogenous level of $N$-palmitoylethanolamine. When 1-anthroyl derivative of $N$-palmitoylethanolamine was analyzed by HPLC equipped with a fluorescence detector, the endogenous level was estimated to be $5.8 \pm 0.7 \mathrm{pmol} / 5 \times 10^{7}$ cells, and the treatment of the cells with $100 \mu \mathrm{M} \mathrm{CCP}$ or $1 \mu \mathrm{M}$ URB597 increased the level by $3.2 \pm 0.1$ fold and $1.4 \pm 0.1$ fold,

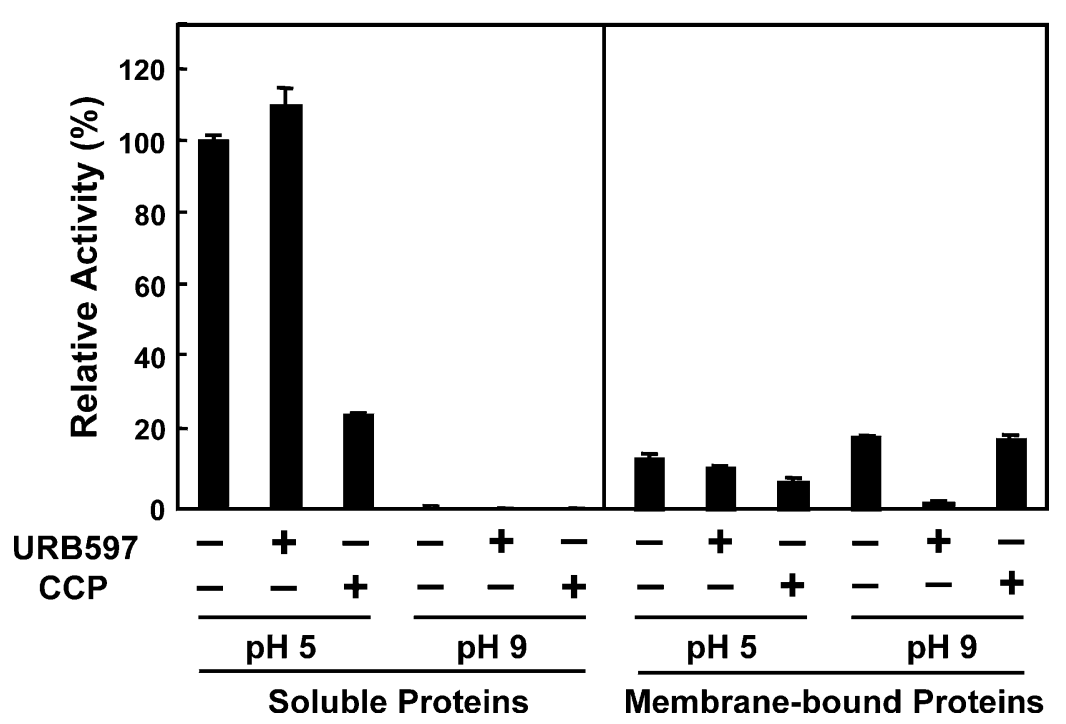

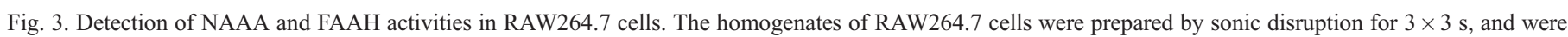

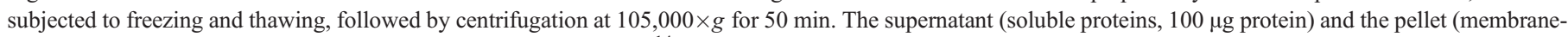

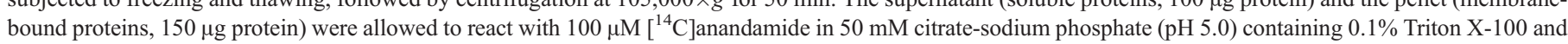

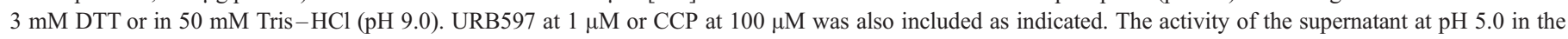
absence of inhibitors $(0.20 \mathrm{nmol} / \mathrm{min}$ per $\mathrm{mg}$ of protein) was expressed as $100 \%$, and relative activities were shown. Means $\pm \mathrm{S} . \mathrm{D}$. are shown $(n=3)$. 

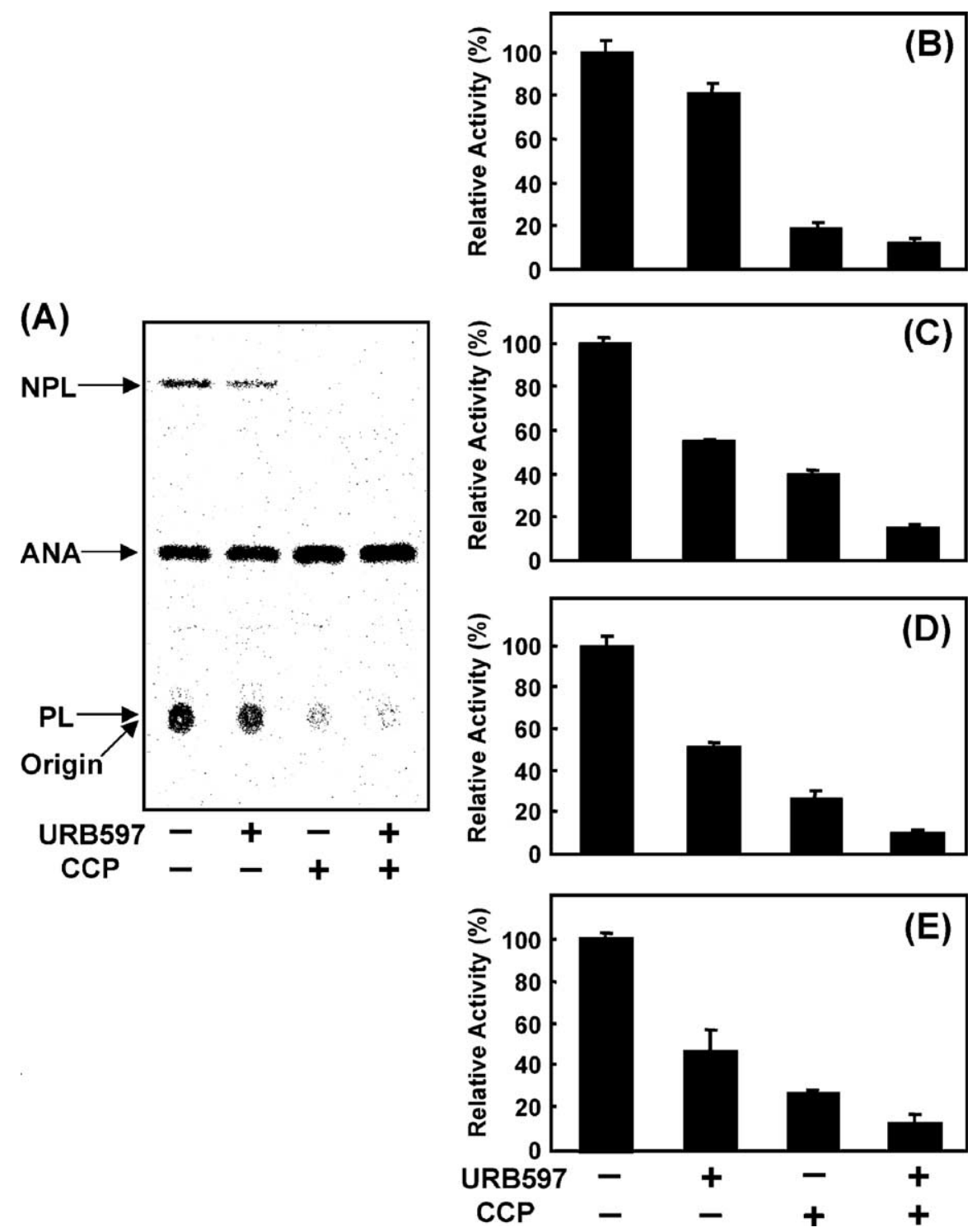

Fig. 4. Inhibitory effects of CCP and URB597 on the $N$-acylethanolamine-hydrolyzing activity in intact RAW264.7 cells. Intact RAW264.7 cells $\left(5 \times 10^{6}\right)$ were suspended in $0.2 \mathrm{ml}$ of RPMI medium 1640 , and preincubated at $37^{\circ} \mathrm{C}$ for $30 \mathrm{~min}$ in the presence of $1 \mu \mathrm{M} \mathrm{URB} 597,100 \mu \mathrm{M} \mathrm{CCP}$, or both or in their absence. The cells were then allowed to react with $25 \mu \mathrm{M}(5000 \mathrm{cpm})$ of $\left[{ }^{14} \mathrm{C}\right]$ anandamide (A and B), $N-\left[{ }^{14} \mathrm{C}\right]$ palmitoylethanolamine $(\mathrm{C}), N-\left[{ }^{14} \mathrm{C}\right]$ oleoylethanolamine (D), and $N$ $\left[{ }^{14} \mathrm{C}\right]$ stearoylethanolamine (E) at $37^{\circ} \mathrm{C}$ for $30 \mathrm{~min}$. A representative thin-layer chromatogram was shown in A. The hydrolysis activities in the absence of inhibitors (B, $42.3 \mathrm{pmol} / \mathrm{min}$; C, $37.3 \mathrm{pmol} / \mathrm{min}$; D, $30.7 \mathrm{pmol} / \mathrm{min}$; E, $5.3 \mathrm{pmol} / \mathrm{min}$ ) were expressed as $100 \%$. Relative activities (means \pm S.D., $n=3$ ) are shown. NPL, nonpolar lipids; ANA, anandamide; PL, polar lipids.

respectively. The results suggested that endogenous levels of $N$-acylethanolamines are also regulated by NAAA and FAAH.

In addition to macrophages, we examined the expression levels of NAAA and FAAH mRNAs in various organs of mice by RT-PCR (Fig. 6). The results showed wide tissue distribution of NAAA mRNA as well as FAAH mRNA. Higher expression levels of NAAA mRNA were observed in lung, brain (cerebrum and cerebellum), and kidney, while the level was very low in liver, and below detection limit in skeletal muscle. On the other hand, FAAH level was the highest in liver, followed by brain and several other organs. The distribution of FAAH mRNA was consistent with the previous report that among various mouse organs the anandamide-hydrolyzing activity was the highest in liver, followed by brain [49]. Since the brain showed relatively high level of
NAAA mRNA, we were interested in a possible contribution of NAAA to the anandamide-hydrolyzing activity in the brain. For comparison, we also examined the liver which expressed the highest level of FAAH but a very low level of NAAA. As shown in Fig. 7, in both mouse liver and brain the activity of the membrane fractions at $\mathrm{pH} 9$ was much higher than that of the soluble fractions at $\mathrm{pH} 5$. Furthermore, the activity at $\mathrm{pH} 9$ was almost completely inhibited by URB597, but not by CCP. Thus, in the brain, the anandamide-hydrolyzing activity appeared to be mostly attributable to FAAH. However, a very low but detectable activity was also observed with the soluble fractions of brain at $\mathrm{pH} 5$ and the activity was sensitive to CCP. The sensitivity to CCP was also confirmed with NAAA partially purified from mouse brain (data not shown). Although the heart showed a relatively high level of NAAA mRNA with 

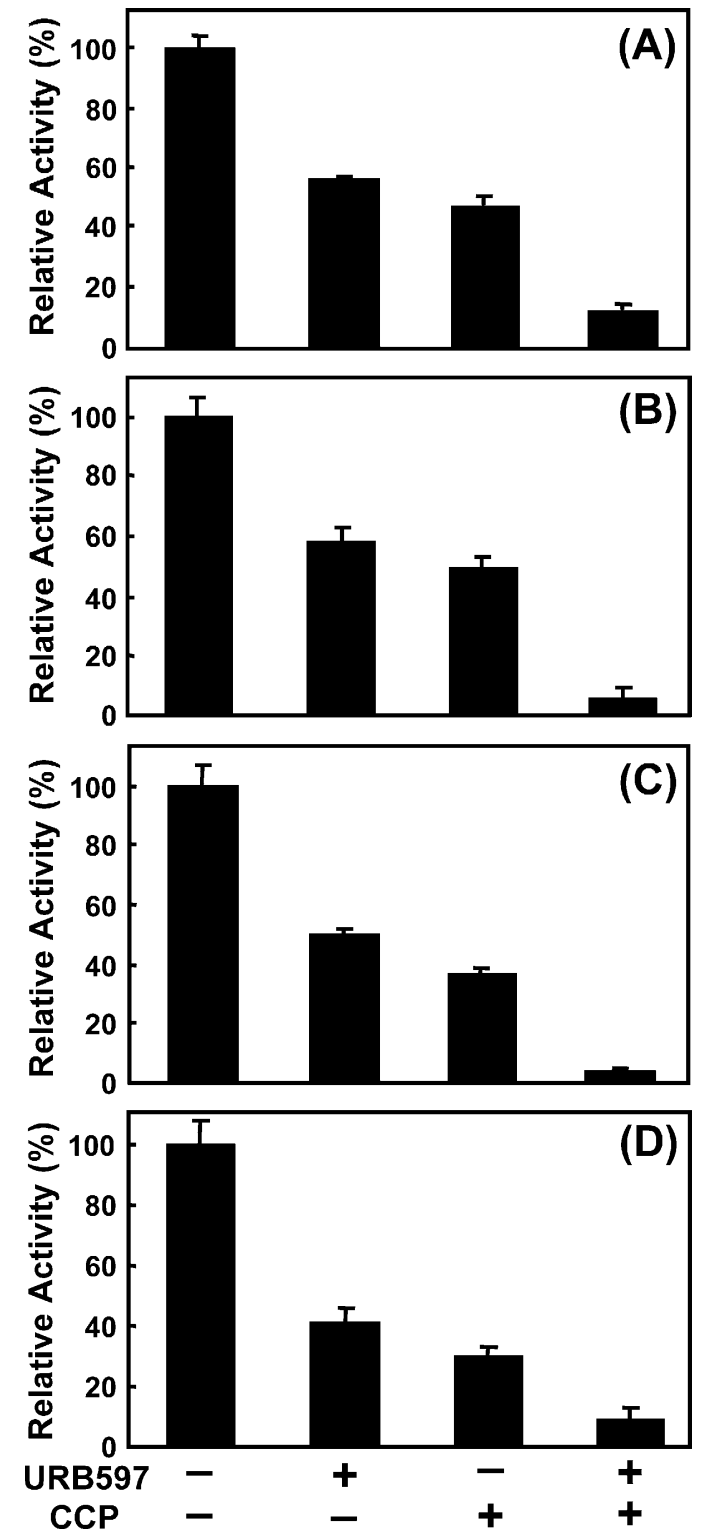

Fig. 5. Inhibitory effects of CCP and URB597 on the $N$-acylethanolaminehydrolyzing activity in intact peritoneal macrophages. Resident macrophages were obtained from the peritoneal cavity of male mice (C57BL/6, Japan SLC) by intraperitoneal injection of $5 \mathrm{ml}$ of PBS twice. The cells $\left(5 \times 10^{6}\right)$ were suspended in $0.2 \mathrm{ml}$ of PBS ( $\mathrm{pH} \mathrm{7.4)}$ ), and preincubated at $37{ }^{\circ} \mathrm{C}$ for $30 \mathrm{~min}$ in the presence of $1 \mu \mathrm{M}$ URB597, $100 \mu \mathrm{M}$ CCP, or both or in their absence. In $\mathrm{A}, \mathrm{NDGA}$ at $10 \mu \mathrm{M}$ was also included as a lipoxygenase inhibitor. The cells were then allowed to react with $25 \mu \mathrm{M}(5000 \mathrm{cpm})$ of $\left[{ }^{14} \mathrm{C}\right]$ anandamide (A), $N-\left[{ }^{14} \mathrm{C}\right]$ palmitoylethanolamine (B), $N-\left[{ }^{14} \mathrm{C}\right]$ oleoylethanolamine (C), and $N-\left[{ }^{14} \mathrm{C}\right]$ stearoylethanolamine (D) at $37{ }^{\circ} \mathrm{C}$ for $30 \mathrm{~min}$. The hydrolysis activities in the absence of inhibitors (A, $11.0 \mathrm{pmol} / \mathrm{min}$; B, $8.3 \mathrm{pmol} / \mathrm{min} ; \mathrm{C}$, $17.7 \mathrm{pmol} / \mathrm{min}$; D, $1.8 \mathrm{pmol} / \mathrm{min}$ ) were expressed as $100 \%$. Relative activities (means \pm S.D., $n=3$ ) are shown.

a very low level of FAAH mRNA (Fig. 6), both the NAAA and FAAH activities were below detection limit with this organ (data not shown).

\section{Discussion}

Our initial studies suggested the presence of a second $\mathrm{N}$ acylethanolamine hydrolase (referred to as NAAA in the present study) in animal tissues, which was catalytically distinguishable from the well-known FAAH [28-30]. Recently, we successfully cloned cDNA of NAAA from human, rat, and mouse, and the deduced amino acid sequences clarified that NAAA has no homology with FAAH but a $33-34 \%$ homology at amino acid level with lysosomal acid ceramidase [31]. Our morphological study with green fluorescent proteinNAAA fusion protein suggested that NAAA also localizes in lysosomes [31]. The localization in lysosomes was in agreement with its optimal $\mathrm{pH}$ at 4.5. Although wide distribution of NAAA in rat tissues suggested its physiological role [29,31], it remained unclear whether this enzyme was actually responsible for the $N$-acylethanolamine degradation in vivo.

FAAH has been studied extensively, including development of specific inhibitors and analyses of FAAH-deficient mice, and its central role in the degradation of anandamide and other $\mathrm{N}$-acylethanolamines is generally accepted [21-25]. However, most studies have been performed without considering a possible coexistence of NAAA in tissues or cells, and the observed $N$-acylethanolamine-hydrolyzing activities were attributed exclusively to FAAH. We should note that the NAAA activity is detectable only at acidic $\mathrm{pH}$ while most enzyme assays have been performed at neutral or alkaline $\mathrm{pH}$ which is suitable to detect FAAH activity. On the other hand, we reported a high NAAA activity in rat macrophages [29], and recently we showed that the NAAA inhibitor CCP inhibited most of the $N$-palmitoylethanolamine-hydrolyzing activity in intact rat alveolar macrophages [42]. These results suggested a possible participation of NAAA in the degradation of $\mathrm{N}$ acylethanolamines in living macrophage cells. However, we have not examined the ability of macrophage NAAA to degrade other $N$-acylethanolamines including anandamide. Moreover, we did not fully consider the involvement of FAAH although the expression of FAAH in macrophages has been reported by others $[38,40,41]$. Therefore, in the present studies
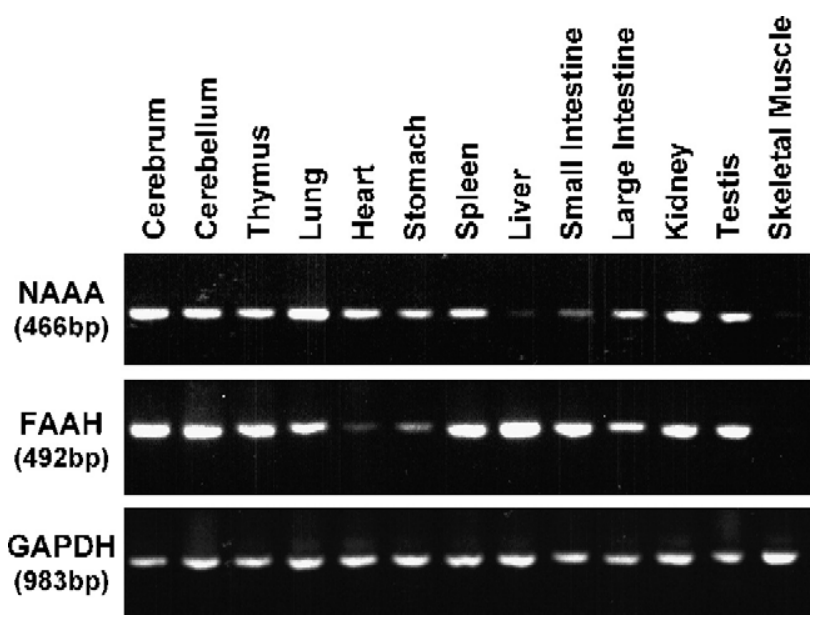

Fig. 6. Distribution of NAAA and FAAH mRNAs in various organs from mice. Total RNAs were isolated from the indicated mouse organs and were analyzed by RT-PCR using primers specific for NAAA, FAAH, and GAPDH. The size of each band is indicated in the parentheses. A representative result of three independent experiments is shown. 


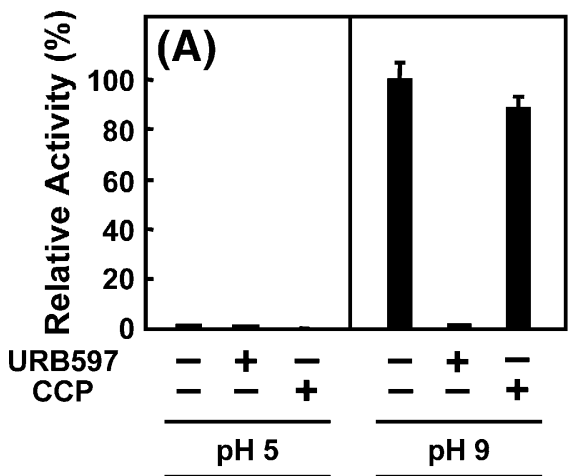

Soluble Proteins Membrane-bound Proteins

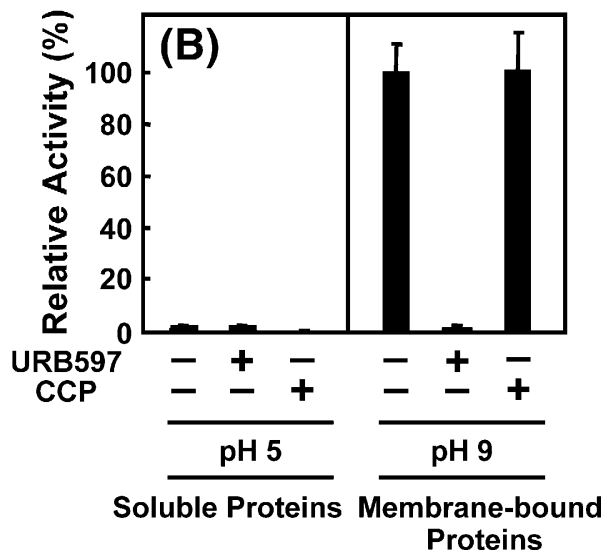

Fig. 7. Detection of NAAA and FAAH activities in mouse liver and brain. The liver and brain of mice were homogenized in 5 times the volume $(\mathrm{v} / \mathrm{w})$ of PBS $(\mathrm{pH}$ 7.4), and the homogenates were subjected to freezing and thawing, followed by centrifugation at $105,000 \times \mathrm{g}$ for $50 \mathrm{~min}$. The supernatant (soluble proteins, $50 \mu \mathrm{g}$ protein) and pellet (membrane-bound proteins, $16 \mu \mathrm{g}$ protein) of the liver (A) and the supernatant (50 $\mu$ g protein) and pellet (50 $\mu$ g protein) of the brain (B) were allowed to react with $100 \mu \mathrm{M}\left[{ }^{14} \mathrm{C}\right]$ anandamide either in 50 $\mathrm{mM}$ citrate-sodium phosphate (pH 5.0) containing $0.1 \%$ Triton X-100 and 3 mM DTT (for the supernatant) or in $50 \mathrm{mM}$ Tris $-\mathrm{HCl}$ ( $\mathrm{pH} 9.0$ ) (for the pellet). URB597 at $3 \mu \mathrm{M}$ (A) or $1 \mu \mathrm{M}$ (B) or CCP at $100 \mu \mathrm{M}$ was also included as indicated. Activity of the pellet in the absence of inhibitor at pH 9.0 (A, 2.6 $\mathrm{nmol} / \mathrm{min}$ per $\mathrm{mg}$ of protein; $\mathrm{B}, 1.0 \mathrm{nmol} / \mathrm{min}$ per $\mathrm{mg}$ of protein) were expressed as $100 \%$, and relative activities were shown. Means \pm S.D. are shown $(n=3)$

we examined whether or not NAAA and FAAH cooperatively degraded various $N$-acylethanolamines in macrophages. For this purpose, we used several established macrophage-like cells and mouse peritoneal macrophages.

The expression of FAAH in rat circulating macrophages [41] and macrophage-like cells such as U937 [40] and RAW264.7 [38] was previously shown at mRNA level by RT-PCR and at protein level by ELISA. The anandamidehydrolyzing activity at $\mathrm{pH}$ 7.6-9.0 was also reported with U937 [40] and RAW264.7 [38] cells. Furthermore, the anandamide-hydrolyzing activity of U937 cells was almost completely abolished by PMSF, a FAAH inhibitor [40]. In agreement with these reports, we also detected FAAH mRNA in mouse peritoneal macrophages and macrophage-like cells (RAW264.7, P388-D1, U937, and THP-1) (Fig. 1). In addition to FAAH, peritoneal macrophages and these cell lines were found to express NAAA (Fig. 1). Previously, we exhibited that the NAAA activity in cell-free preparations could be distinguishable from the FAAH activity based on different $\mathrm{pH}$ dependency and different subcellular distribution [28,31]. At $\mathrm{pH}$ 9, FAAH showed the highest activity while NAAA was almost inactive. In contrast, at $\mathrm{pH}$ 5, NAAA showed almost full activity while FAAH was much less active. As to subcellular distribution, NAAA was easily solubilized from the particulate fractions by freezing and thawing, while FAAH remained tightly bound to the membrane [28]. Thus, the $\mathrm{N}$-acylethanolamine-hydrolyzing activity at $\mathrm{pH} 5$ with the soluble fractions was presumed to be derived mostly from NAAA, and that at pH 9 with the membrane fractions mostly from FAAH. In the present study, the appropriateness of this assumption was confirmed by the use of CCP and URB597 as a specific NAAA inhibitor and a specific FAAH inhibitor, respectively. By this method, we could detect the NAAA activity and to a lesser extent the FAAH activity in the homogenates of RAW264.7 cells (Fig. 3).

Among a vast number of FAAH inhibitors so far developed [21-24], URB597 appeared to be one of the most potent inhibitors. The compound inhibited FAAH in rat brain membrane preparations [44] and intact cortical neurons [43] with $\mathrm{IC}_{50}$ values of $4.6 \mathrm{nM}$ and $0.50 \mathrm{nM}$, respectively. Interestingly, URB597 exerted an anxiolytic effect in rat [43]. We showed that URB597 dose-dependently inhibited rat liver FAAH with an $\mathrm{IC}_{50}$ of $0.07 \mu \mathrm{M}$ while it did not inhibit rat lung NAAA at concentrations at least up to $10 \mu \mathrm{M}$ (Fig. 2). Very recently, Fegley et al. also reported that URB597 at 1 $\mu \mathrm{M}$ did not affect $N$-palmitoylethanolamine-preferring acid amidase activity of rat duodenum [50]. On the other hand, we recently found that $\mathrm{CCP}$ dose-dependently inhibited NAAA with an $\mathrm{IC}_{50}$ of $4.5 \mu \mathrm{M}$ without inhibiting FAAH at concentrations up to $100 \mu \mathrm{M}$ [42]. Furthermore, CCP inhibited recombinant NAAA [31], but not recombinant FAAH (unpublished observation) in intact HEK293 cells overexpressing each enzyme.

We showed that RAW264.7 cells and resident macrophages of mouse peritoneal cavity have ability to degrade anandamide, $N$-palmitoylethanolamine, $N$-oleoylethanolamine, and $\mathrm{N}$-stearoylethanolamine when intact cells were incubated with these substrates exogenously added (Figs. 4 and 5). The degradation rates of anandamide, $N$-palmitoylethanolamine, and $N$-oleoylethanolamine were similar to each other, but that of $N$-stearoylethanolamine was much lower. FAAH was previously reported to be the most active with anandamide among various $N$-acylethanolamines [21], while NAAA was the most active with $N$-palmitoylethanolamine [29,31]. However, the preference for anandamide or $N$ palmitoylethanolamine was not observed with FAAH and NAAA isolated from RAW264.7 cells. Further studies will be required to clarify the reason why substrate specificity of the crude enzymes from RAW264.7 cells $\backslash$ is different from those of pure enzymes previously reported. Moreover, the mechanism and rate of cellular uptake appeared to differ among various $N$-acylethanolamines [51,52]. Thus, it seems that the degradation rate of each $N$-acylethanolamine in intact cells cannot be explained simply by substrate 
specificity of pure enzymes and is determined by multiple factors.

Both CCP and URB597 partially inhibited the degradation of $N$-acylethanolamines in intact RAW264.7 cells and mouse peritoneal macrophages, and a combination of the two inhibitors caused more profound inhibition (Figs. 4 and 5). These results suggested that NAAA and FAAH cooperatively degraded $N$-acylethanolamines in macrophages. This finding might partly explain the previous finding that the level of anandamide in peritoneal macrophages of FAAH-deficient mice was only 2 - to 2.5 -fold higher than that in wild-type mice [38]. However, we could not rule out the possibility that enzymes other than NAAA and FAAH are also responsible for the degradation. In fact, anandamide, but not other $\mathrm{N}$ acylethanolamines, was converted to polar compounds in peritoneal macrophages probably by lipoxygenase (data not shown), as reported previously with human platelets and polymorphonuclear leukocytes [53]. Since we have reported that acid ceramidase also showed an $\mathrm{N}$-acylethanolaminehydrolyzing activity at acidic $\mathrm{pH}[31]$, it was likely that not only NAAA but also acid ceramidase contributed to the $\mathrm{N}$ acylethanolamine-hydrolyzing activity at $\mathrm{pH} 5$. We actually detected a low, but measurable activity $(0.020 \mathrm{nmol} / \mathrm{min}$ per $\mathrm{mg}$ of protein) of acid ceramidase in the homogenates of RAW264.7 cells with $N$-lauroylsphingosine (C12-ceramide) as substrate. In order to distinguish these two enzymes, we utilized their difference in the sensitivity to DTT. Namely, it was reported that DTT dose-dependently stimulated NAAA activity up to 6.9-fold, while DTT hardly increased the $N$ acylethanolamine-hydrolyzing activity of acid ceramidase [31]. Since DTT at $3 \mathrm{mM}$ actually stimulated the hydrolysis activity of $\mathrm{N}$-palmitoylethanolamine and anandamide by $4.3-$ to 5.8 fold at $\mathrm{pH} 5$ with the soluble proteins of RAW264.7 cell homogenates, the activity was suggested to be mostly derived from NAAA rather than acid ceramidase.

We examined for the first time the tissue distribution of NAAA mRNA in mice (Fig. 6). Although the results were similar to the distribution in rats which we reported recently [31], some differences were found. In both rats and mice, the highest expression level was seen with lung. In addition, mice showed relatively high expression levels in brain and kidney, but those in rats were low. The wide distribution of NAAA suggested its contribution to the $N$-acylethanolamine degradation in various mice organs. Since the brain is considered to be the site where anandamide acts as an endocannabinoid, we noted the relatively high expression of NAAA mRNA in mouse brain. However, our enzyme assays suggested that the anandamide-hydrolyzing activity in the brain is mostly attributable to FAAH rather than NAAA. The CCP-sensitive activity was also detected at $\mathrm{pH} 5$ in the brain, but it was considerably lower than the FAAH activity. Further investigation will be necessary for the discrepancy between the relatively high mRNA level and the low activity. Since it is possible that certain brain regions express higher levels of NAAA, morphological studies on the regional distribution of NAAA in the brain may help us to elucidate a role of NAAA in this organ.
The predominant activity of FAAH in the brain was consistent with the previous observation that FAAH-deficient mice possessed greatly augmented endogenous brain levels of anandamide, $\mathrm{N}$-palmitoylethanolamine, and $\mathrm{N}$-oleoylethanolamine relative to wild-type mice [26,27,50]. Furthermore, administration of URB597 to rodents resulted in 3- to 6-fold augmented endogenous brain levels of these three $N$ acylethanolamines [43]. Similar results were reported with brain and spinal cord of mice to which OL-135, another FAAH inhibitor, was administrated [54]. Interestingly, it was reported very recently that URB597 did not affect the endogenous levels of anandamide, $N$-palmitoylethanolamine, and $N$-oleoylethanolamine in rat duodenum [50]. In addition, an NAAA-like activity was detected with the duodenum of FAAH-deficient mice. Based on these results, the authors suggested that, contrary to the case with the central nervous system, FAAH does not play the major role in the deactivation of $N$-acylethanolamine in the small intestine, and referred to a possible involvement of NAAA. Immunohistochemical and in situ hybridization analyses will be required for further studies on the physiological roles of NAAA in various tissues and cells.

In summary, we revealed the coexpression of NAAA and FAAH in resident macrophages and macrophage-like cells, and suggested participation of both the enzymes in the degradation of various bioactive $N$-acylethanolamines in macrophages. The wide distribution of NAAA in mouse tissues also suggested its physiological roles in other tissues.

\section{Acknowledgement}

This work was supported by Grant-in-Aid for Scientific Research from the Ministry of Education, Culture, Sports, Science, and Technology of Japan.

\section{References}

[1] H.H.O. Schmid, P.C. Schmid, V. Natarajan, $N$-Acylated glycerophospholipids and their derivatives, Prog. Lipid Res. 29 (1990) 1-43.

[2] H.S. Hansen, B. Moesgaard, H.H. Hansen, G. Petersen, N-Acylethanolamines and precursor phospholipids-Relation to cell injury, Chem. Phys. Lipids 108 (2000) 135-150.

[3] H.H.O. Schmid, E.V. Berdyshev, Cannabinoid receptor-inactive $N$ acylethanolamines and other fatty acid amides: metabolism and function, Prostaglandins Leukot. Essent. Fat. Acids 66 (2002) 363-376.

[4] T. Sugiura, Y. Kobayashi, S. Oka, K. Waku, Biosynthesis and degradation of anandamide and 2-arachidonoylglycerol and their possible physiological significance, Prostaglandins Leukot. Essent. Fat. Acids 66 (2002) $173-192$

[5] W.A. Devane, L. Hanus, A. Breuer, R.G. Pertwee, L.A. Stevenson, G. Griffin, D. Gibson, A. Mandelbaum, A. Etinger, R. Mechoulam, Isolation and structure of a brain constituent that binds to the cannabinoid receptor, Science 258 (1992) 1946-1949.

[6] V. Di Marzo, 'Endocannabinoids' and other fatty acid derivatives with cannabimimetic properties: biochemistry and possible physiopathological relevance, Biochim. Biophys. Acta 1392 (1998) 153-175.

[7] M. van der Stelt, V. Di Marzo, Endovanilloids, Eur. J. Biochem. 271 (2004) $1827-1834$.

[8] A. Calignano, G. La Rana, A. Giuffrida, D. Piomelli, Control of pain initiation by endogenous cannabinoids, Nature 394 (1998) 277-281.

[9] A. Calignano, G. La Rana, D. Piomelli, Antinociceptive activity of the 
endogenous fatty acid amide, palmitylethanolamide, Eur. J. Pharmacol. 419 (2001) $191-198$.

[10] D.M. Lambert, S. Vandevoorde, K.O. Jonsson, C.J. Fowler, The palmitoylethanolamide family: a new class of anti-inflammatory agents? Curr. Med. Chem. 9 (2002) 663-674.

[11] J. Lo Verme, J. Fu, G. Astarita, G. La Rana, R. Russo, A. Calignano, D. Piomelli, The nuclear receptor peroxisome proliferator-activated receptor$\alpha$ mediates the anti-inflammatory actions of palmitoylethanolamide, Mol. Pharmacol. 67 (2005) 15-19.

[12] F. Rodríguez de Fonseca, M. Navarro, R. Gomez, L. Escuredo, F. Nava, J. Fu, E. Murillo-Rodríguez, A. Giuffrida, J. LoVerme, S. Gaetani, S. Kathuria, C. Gall, D. Piomelli, An anorexic lipid mediator regulated by feeding, Nature 414 (2001) 209-212.

[13] J. Fu, S. Gaetani, F. Oveisi, J. Lo Verme, A. Serrano, F. Rodríguez de Fonseca, A. Rosengarth, H. Luecke, B. Di Giacomo, G. Tarzia, D. Piomelli, Oleylethanolamide regulates feeding and body weight through activation of the nuclear receptor PPAR- $\alpha$, Nature 425 (2003) 90-93.

[14] M. Maccarrone, R. Pauselli, M. Di Rienzo, A. Finazzi-Agro, Binding, degradation and apoptotic activity of stearoylethanolamide in rat $\mathrm{C} 6$ glioma cells, Biochem. J. 366 (2002) 137-144.

[15] S. Terrazzino, F. Berto, M. Dalle Carbonare, M. Fabris, A. Guiotto, D. Bernardini, A. Leon, Stearoylethanolamide exerts anorexic effects in mice via down-regulation of liver stearoyl-coenzyme A desaturase-1 mRNA expression, FASEB J. 18 (2004) 1580-1582.

[16] D.E. Epps, P.C. Schmid, V. Natarajan, H.H.O. Schmid, N-Acylethanolamine accumulation in infarcted myocardium, Biochem. Biophys. Res. Commun. 90 (1979) 628-633.

[17] P.C. Schmid, R.J. Krebsbach, S.R. Perry, T.M. Dettmer, J.L. Maasson, H.H.O. Schmid, Occurrence and postmortem generation of anandamide and other long-chain $\mathrm{N}$-acylethanolamines in mammalian brain, FEBS Lett. 375 (1995) 117-120 (Correction FEBS Lett. 385 (1996) 125).

[18] H.S. Hansen, L. Lauritzen, A.M. Strand, B. Moesgaard, A. Frandsen, Glutamate stimulates the formation of $N$-acylphosphatidylethanolamine and $N$-acylethanolamine in cortical neurons in culture, Biochim. Biophys. Acta 1258 (1995) 303-308.

[19] S. Kondo, T. Sugiura, T. Kodaka, N. Kudo, K. Waku, A. Tokumura, Accumulation of various $N$-acylethanolamines including $N$-arachidonoylethanolamine (anandamide) in cadmium chloride-administered rat testis, Arch. Biochem. Biophys. 354 (1998) 303-310.

[20] Y. Okamoto, J. Morishita, K. Tsuboi, T. Tonai, N. Ueda, Molecular characterization of a phospholipase D generating anandamide and its congeners, J. Biol. Chem. 279 (2004) 5298-5305.

[21] N. Ueda, R.A. Puffenbarger, S. Yamamoto, D.G. Deutsch, The fatty acid amide hydrolase (FAAH), Chem. Phys. Lipids 108 (2000) 107-121.

[22] N. Ueda, Endocannabinoid hydrolases, Prostaglandins Other Lipid Mediat. 68-69 (2002) 521-534.

[23] T. Bisogno, L. De Petrocellis, V. Di Marzo, Fatty acid amide hydrolase, an enzyme with many bioactive substrates. Possible therapeutic implications, Curr. Pharm. Des. 8 (2002) 533-547.

[24] B.F. Cravatt, A.H. Lichtman, Fatty acid amide hydrolase: an emerging therapeutic target in the endocannabinoid system, Curr. Opin. Chem. Biol 7 (2003) 469-475.

[25] M.K. McKinney, B.F. Cravatt, Structure and function of fatty acid amide hydrolase, Annu. Rev. Biochem. 74 (2005) 411-432.

[26] B.F. Cravatt, K. Demarest, M.P. Patricelli, M.H. Bracey, D.K. Giang, B.R. Martin, A.H. Lichtman, Supersensitivity to anandamide and enhanced endogenous cannabinoid signaling in mice lacking fatty acid amide hydrolase, Proc. Natl. Acad. Sci. U. S. A. 98 (2001) 9371-9376.

[27] A.B. Clement, E.G. Hawkins, A.H. Lichtman, B.F. Cravatt, Increased seizure susceptibility and proconvulsant activity of anandamide in mice lacking fatty acid amide hydrolase, J. Neurosci. 23 (2003) $3916-3923$.

[28] N. Ueda, K. Yamanaka, Y. Terasawa, S. Yamamoto, An acid amidase hydrolyzing anandamide as an endogenous ligand for cannabinoid receptors, FEBS Lett. 454 (1999) 267-270.

[29] N. Ueda, K. Yamanaka, S. Yamamoto, Purification and characterization of an acid amidase selective for $N$-palmitoylethanolamine, a putative endogenous anti-inflammatory substance, J. Biol. Chem. 276 (2001) $35552-35557$.

[30] N. Ueda, K. Tsuboi, D.M. Lambert, A second $N$-acylethanolamine hydrolase in mammalian tissues, Neuropharmacology 48 (2005) $1079-1085$.

[31] K. Tsuboi, Y.-X. Sun, Y. Okamoto, N. Araki, T. Tonai, N. Ueda, Molecular characterization of $N$-acylethanolamine-hydrolyzing acid amidase, a novel member of the choloylglycine hydrolase family with structural and functional similarity to acid ceramidase, J. Biol. Chem. 280 (2005) $11082-11092$.

[32] V. Di Marzo, L. De Petrocellis, N. Sepe, A. Buono, Biosynthesis of anandamide and related acylethanolamides in mouse J774 macrophages and $\mathrm{N}_{18}$ neuroblastoma cells, Biochem. J. 316 (1996) 977-984.

[33] J.A. Wagner, K. Varga, E.F. Ellis, B.A. Rzigalinski, B.R. Martin, G. Kunos, Activation of peripheral $\mathrm{CB}_{1}$ cannabinoid receptors in haemorrhagic shock, Nature 390 (1997) 518-521.

[34] T. Bisogno, S. Maurelli, D. Melck, L. De Petrocellis, V. Di Marzo, Biosynthesis, uptake, and degradation of anandamide and palmitoylethanolamide in leukocytes, J. Biol. Chem. 272 (1997) 3315-3323.

[35] P.C. Schmid, T. Kuwae, R.J. Krebsbach, H.H.O. Schmid, Anandamide and other $\mathrm{N}$-acylethanolamines in mouse peritoneal macrophages, Chem. Phys. Lipids 87 (1997) 103-110.

[36] K. Varga, J.A. Wagner, D.T. Bridgen, G. Kunos, Platelet- and macrophage-derived endogenous cannabinoids are involved in endotoxininduced hypotension, FASEB J. 12 (1998) 1035-1044.

[37] T. Kuwae, Y. Shiota, P.C. Schmid, R. Krebsbach, H.H.O. Schmid, Biosynthesis and turnover of anandamide and other $N$-acylethanolamines in peritoneal macrophages, FEBS Lett. 459 (1999) 123-127.

[38] J. Liu, S. Bátkai, P. Pacher, J. Harvey-White, J.A. Wagner, B.F. Cravatt, B. Gao, G. Kunos, Lipopolysaccharide induces anandamide synthesis in macrophages via CD14/MAPK/phosphoinositide 3-kinase/NF-kB independently of platelet-activating factor, J. Biol. Chem. 278 (2003) 45034-45039.

[39] R.A. Ross, H.C. Brockie, R.G. Pertwee, Inhibition of nitric oxide production in RAW264.7 macrophages by cannabinoids and palmitoylethanolamide, Eur. J. Pharmacol. 401 (2000) 121-130.

[40] M. Maccarrone, M. van der Stelt, A. Rossi, G.A. Veldink, J.F.G. Vliegenthart, A.F. Agrò, Anandamide hydrolysis by human cells in culture and brain, J. Biol. Chem. 273 (1998) 32332-32339.

[41] V. Di Marzo, T. Bisogno, L. De Petrocellis, D. Melck, P. Orlando, J.A. Wagner, G. Kunos, Biosynthesis and inactivation of the endocannabinoid 2-arachidonoylglycerol in circulating and tumoral macrophages, Eur. J. Biochem. 264 (1999) 258-267.

[42] K. Tsuboi, C. Hilligsmann, S. Vandevoorde, D.M. Lambert, N. Ueda, $\mathrm{N}$-Cyclohexanecarbonylpentadecylamine: a selective inhibitor of the acid amidase hydrolysing $\mathrm{N}$-acylethanolamines, as a tool to distinguish acid amidase from fatty acid amide hydrolase, Biochem. J. 379 (2004) 99-106.

[43] S. Kathuria, S. Gaetani, D. Fegley, F. Valiño, A. Duranti, A. Tontini, M. Mor, G. Tarzia, G. La Rana, A. Calignano, A. Giustino, M. Tattoli, M. Palmery, V. Cuomo, D. Piomelli, Modulation of anxiety through blockade of anandamide hydrolysis, Nat. Med. 9 (2003) 76-81.

[44] M. Mor, S. Rivara, A. Lodola, P.V. Plazzi, G. Tarzia, A. Duranti, A. Tontini, G. Piersanti, S. Kathuria, D. Piomelli, Cyclohexylcarbamic acid 3'- or 4'-substituted biphenyl-3-yl esters as fatty acid amide hydrolase inhibitors: synthesis, quantitative structure-activity relationships, and molecular modeling studies, J. Med. Chem. 47 (2004) $4998-5008$.

[45] N. Ueda, K. Yamamoto, S. Yamamoto, T. Tokunaga, E. Shirakawa, H. Shinkai, M. Ogawa, T. Sato, I. Kudo, K. Inoue, H. Takizawa, T. Nagano, M. Hirobe, N. Matsuki, H. Saito, Lipoxygenase-catalyzed oxygenation of arachidonylethanolamide, a cannabinoid receptor agonist, Biochim. Biophys. Acta 1254 (1995) 127-134.

[46] M.M. Bradford, A rapid and sensitive method for the quantitation of microgram quantities of protein utilizing the principle of protein-dye binding, Anal. Biochem. 72 (1976) 248-254.

[47] T. Sugiura, S. Kondo, A. Sukagawa, T. Tonegawa, S. Nakane, A. Yamashita, Y. Ishima, K. Waku, Transacylase-mediated and phosphodi- 
esterase-mediated synthesis of $N$-arachidonoylethanolamine, an endogenous cannabinoid-receptor ligand, in rat brain microsomes. Comparison with synthesis from free arachidonic acid and ethanolamine, Eur. J. Biochem. 240 (1996) 53-62.

[48] J. Freire-Moar, A. Alavi-Nassab, M. Ng, M. Mulkins, E. Sigal, Cloning and characterization of a murine macrophage lipoxygenase, Biochim. Biophys. Acta 1254 (1995) 112-116.

[49] K. Watanabe, H. Ogi, S. Nakamura, Y. Kayano, T. Matsunaga, H. Yoshimura, I. Yamamoto, Distribution and characterization of anandamide amidohydrolase in mouse brain and liver, Life Sci. 62 (1998) 1223-1229.

[50] D. Fegley, S. Gaetani, A. Duranti, A. Tontini, M. Mor, G. Tarzia, D. Piomelli, Characterization of the fatty acid amide hydrolase inhibitor cyclohexyl carbamic acid 3'-carbamoyl-biphenyl-3-yl ester (URB597): effects on anandamide and oleoylethanolamide deactivation, J. Pharmacol. Exp. Ther. 313 (2005) 352-358.

[51] S.O.P. Jacobsson, C.J. Fowler, Characterization of palmitoylethanolamide transport in mouse Neuro-2a neuroblastoma and rat RBL-2H3 basophilic leukaemia cells: comparison with anandamide, Br. J. Pharmacol. 132 (2001) $1743-1754$.

[52] C.J. Fowler, S.O.P. Jacobsson, Cellular transport of anandamide, 2arachidonoylglycerol and palmitoylethanolamide - Targets for drug development? Prostaglandins Leukot. Essent. Fat. Acids 66 (2002) 193-200.

[53] W.S. Edgemond, C.J. Hillard, J.R. Falck, C.S. Kearn, W.B. Campbell, Human platelets and polymorphonuclear leukocytes synthesize oxygenated derivatives of arachidonylethanolamide (anandamide): their affinities for cannabinoid receptors and pathways of inactivation, Mol. Pharmacol. 54 (1998) $180-188$.

[54] A.H. Lichtman, D. Leung, C.C. Shelton, A. Saghatelian, C. Hardouin, D.L. Boger, B.F. Cravatt, Reversible inhibitors of fatty acid amide hydrolase that promote analgesia: evidence for an unprecedented combination of potency and selectivity, J. Pharmacol. Exp. Ther. 311 (2004) 441-448. 